Article

\title{
Whose Rules? A Water Justice Critique of the OECD's 12 Principles on Water Governance
}

\author{
Katherine Selena Taylor ${ }^{1, *(D)}$, Sheri Longboat ${ }^{2}$ and Rupert Quentin Grafton ${ }^{1}(\mathbb{D}$ \\ 1 Crawford School of Public Policy, Australian National University, Canberra, ACT 2601, Australia; \\ quentin.grafton@anu.edu.au \\ 2 School of Environmental Design and Rural Development, University of Guelph, Guelph, ON N1G 2W1, \\ Canada; slongboat@uoguelph.ca \\ * Correspondence: katherine.taylor@anu.edu.au; Tel.: +61-458-287-721
}

Received: 10 December 2018; Accepted: 5 April 2019; Published: 18 April 2019

\begin{abstract}
The article constructively critiques the Organization for Economic Cooperation and Development's (OECD) 12 Principles on Water Governance (the OECD Principles). The human rights standard, the United Nations Declaration on the Rights of Indigenous Peoples (UNDRIP), provided the foundation for conceptualizing Indigenous water rights. The analysis used a modification of Zwarteveen and Boelens' 2014 framework of the four echelons of water contestation. The analysis indicates that the OECD Principles assume state authority over water governance, make invisible Indigenous peoples' own water governance systems and perpetuate the discourses of water colonialism. Drawing on Indigenous peoples' water declarations, the Anishinaabe 'Seven Grandfathers' as water governance principles and Haudenosaunee examples, we demonstrate that the OECD Principles privilege certain understandings of water over others, reinforcing the dominant discourses of water as a resource and water governance based on extractive relationships with water. Reconciling the OECD Principles with UNDRIP's human rights standard promotes Indigenous water justice. One option is to develop a reinterpretation of the OECD Principles. A second, potentially more substantive option is to review and reform the OECD Principles. A reform might consider adding a new dimension, 'water justice,' to the OECD Principles. Before reinterpretation or reform can occur, broader input is needed, and inclusion of Indigenous peoples into that process.
\end{abstract}

Keywords: First Nations; OECD; water governance; water justice; water colonialism; UNDRIP; UN Declaration on the Rights of Indigenous Peoples

\section{Introduction}

In 2007, the United Nations Declaration on the Rights of Indigenous Peoples (UNDRIP) became the international standard for Indigenous peoples' rights [1]. UNDRIP provides a framework, based on the principle of self-determination, for understanding Indigenous water justice [2]. The implication for water management is that Indigenous peoples have the right to manage and use their waters and lands according to their own systems of water governance.

Unfortunately, the water sector has been slow to respond to the implications of UNDRIP. Settler state water governance systems at all scales have failed Indigenous peoples [3]. Settler state institutions tend to exclude, override or ignore Indigenous peoples' water governance. This process of systematic exclusion, based on colonial imperialism, has been termed 'water colonialism' [2].

A growing literature documents and theorizes Indigenous water (in)justice. Much of the analysis in the literature is based on the scale of settler states/Indigenous peoples. Fewer analyses consider international water governance standards and guidelines. One of these guidelines is the Organization 
for Economic Co-operation and Development (OECD)'s 12 Principles on Water Governance, referred to here as the 'OECD Principles'.

The impact of non-binding international guidelines, like the OECD Principles, on actual water governance practices can be disputed. These guidelines, nonetheless, have a role in shaping water governance discourse. If we accept that the role of the OECD Principles is to provide a robust, internationally accepted framework for water governance, then the potential impact of the OECD Principles on Indigenous water justice must be fully considered.

Using a framework based on Zwarteveen \& Boelens' four echelons of water contestation [4], we provide a critique of the OECD Principles. Our constructive critique explores some of the underlying tensions between the discourses of the OECD Principles and the examples of Indigenous peoples' water governance. Based on this critique, potential pathways are discussed and options are explored for reform.

Given the diversity of Indigenous peoples, we did not wish to generalize on what Indigenous peoples' water governance is or is not. Nevertheless, the underlying ontological foundations of water governance are worth examining in relation to water colonialism. In order to make comparisons as part of the critique, we draw on a number of examples, including: The Great Lakes Anishinaabe 'Seven Grandfathers' as water governance principles, the Haudenosaunee Confederacy (Six Nations) Great Law of Peace as governance principles, the Ontario Water Declaration, the Assembly of First Nations' National Water Declaration, the Fitzroy Declaration, the Garma Declaration, and the Kyoto Indigenous Peoples' Water Declaration.

Through this article, 'water' and 'waters' refer to freshwater only. Sea or offshore water rights are not discussed here. Water is connected within the landscape, so when we refer to 'water', this includes groundwater and springs, as well as larger water bodies and rivers.

As noted in the Australia and New Zealand Indigenous Principles for Water Quality, the 'land, sky, water and its people are inseparable' [5]. But, a separation of land and water is embedded in many systems of water governance and management. Indeed, it is the basis on denying many Indigenous peoples their water rights, even if land rights are recognized. The artificial separation of land and water governance is preserved here for cohesiveness across our critique.

Throughout most of this article 'rights' and 'Indigenous water rights' are meant in the broad sense: Economic, social, cultural, political or other rights to water. When referring to a formal, state recognized right to take a volume of water, such as a water license, water allocation, or water property right, we use the term 'water entitlement'.

\section{Background}

It is a truism that water crises are crises of governance. It follows that one of the solutions to water crisis is 'good' or 'best practice' governance. These ostensibly neutral terms describe systems that are shaped by politics, power and economic interests. Perreault notes that 'the vagueness and malleability of the term may serve to obscure political interest and ideological positions, as in the World Bank's formulaic calls for 'good governance', a position that is surely hard to argue with. After all, who wants bad governance?' [6]. Engaging critically with the politics of 'good governance' makes visible the contested claims about who governs, what constitutes 'good' governance, and the claims to water itself.

\subsection{The OECD 12 Principles on Water Governance}

The Organization for Economic Cooperation and Development's 12 Principles on Water Governance is a framework described by the OECD as, 'must-do for governments to design and implement effective, efficient, and inclusive water policies' [7]. The principles are intended to improve the 'water governance cycle', from policy conception to implementation, based around three dimensions: 'Effectiveness', 'efficiency', and 'trust and engagement'. Table 1 below lists the Principles. The OECD Principles are accompanied by an assessment tool containing indicators for 
each principle [8]. The OECD Principles are included within the OECD Council Recommendation on Water [9].

Table 1. The 3 dimensions of the OECD 12 Principles on Water Governance.

\begin{tabular}{ccc}
\hline Dimension & Principle \# & Principle \\
\hline \multirow{4}{*}{ Effectiveness } & Principle 1 & Clear roles and responsibilities \\
& Principle 2 & Principle 3 \\
& Principle 4 & Policy coherence \\
& Principle 5 & Capacity \\
\hline \multirow{2}{*}{ Efficiency } & Principle 6 & Data and information \\
& Principle 7 & Financing \\
& Principle 8 & Regulatory frameworks \\
& Principle 9 & Innovative governance \\
\hline \multirow{2}{*}{ Trust \& engagement } & Principle 10 & Integrity and transparency \\
& Principle 11 & Trade-offs across users, rural and urban areas, and generations \\
& Principle 12 & Monitoring and evaluation \\
\hline
\end{tabular}

The OECD Principles are presented as a neutral and flexible tool. The principles do not distinguish between water management functions, uses or ownership [10]. They are non-binding and non-prescriptive. This is appropriate because there is no 'one-size-fits-all' approach to water policy. Documentation about the OECD Principles emphasizes the importance of contextual factors and place-based needs [11].

The development of the OECD Principles is consistent with the OECD's mission to 'promote policies that will improve the economic and social wellbeing of people around the world' [12]. The OECD evolved from the Organization for European Economic Cooperation (OEEC), which was formed in 1948 to enhance European cooperation after World War II [13]. Canada and the USA joined the OEEC in 1960, extending the membership beyond Europe and creating the OECD. Canada and the USA, along with Australia and New Zealand (also OECD members) are often linked due to their history of British settler colonialism. These countries voted against UNDRIP in 2007, although all four later reversed their position. The OECD's mission, combined with its membership, form the backdrop on which the OECD Principles were formed.

The OECD Principles were developed through the Water Governance Initiative (WGI), initiated in 2013 by the OECD [14]. The WGI has a role in the 'global water governance agenda' and reports helping 'shape national reform agenda and strategic plans (e.g., Mexico's new National Water Law)' [15]. The WGI contributed to several international water documents, such as the Lisbon Charter [16]. Although the WGI does not have decision-making authority, its advisory network shares information between a range of experts, policy makers, and practitioners.

To develop the OECD Principles, more than 100 participants were involved from the public, private and not-for-profit sectors. The WGI's final Principles were adopted by the OECD Regional Development Committee in 2015. A Global Coalition for Good Water Governance was convened of parties that endorsed the OECD Principles [14].

The OECD Principles are now endorsed by more than 170 entities, including 41 countries. Endorsement is a commitment to using the Principles, disseminating the Principles, and reporting back to the OECD.

Despite their growing acceptance and use, it is difficult to evaluate the extent to which the OECD Principles have directly impacted or improved practices. In 2018, the OECD surveyed the Global Coalition for Good Water Governance: $80 \%$ of the 85 respondents reported using the OECD Principles to inform policy or make other decisions; $42 \%$ reported using the OECD Principles to assess water governance in particular contexts; and 25\% said the Principles were used to guide practices in their 
own organizations [14]. But, only 28\% reported using the Principles as a 'package.' Other respondents reported that individual Principles were used, depending on the context. The report does not provide a breakdown of results by sector, so it is unclear how the relative uptake by government compares to the private sector, for example.

The literature contains several examples of the OECD Principles being used as an analytical and auditing tool. The OECD Principles were used to compare water governance policies across six countries [17], to discuss changes in France's water governance [18], and assess the Dutch Flood Protection Program [19]. A key conclusion of the Dutch assessment was the importance of focusing on actual practices, not only on the overarching governance processes. These studies indicate the OECD Principles' analytical utility.

\subsection{Indigenous Water Justice and Water Colonialism}

Settler states have tended to claim authority over water, excluding and obscuring Indigenous peoples' systems of water governance. The claiming of waters by states, as part of the claiming of land and other resources, is an intrinsic and ongoing part of colonization [3,20]. Following Robison et al., we use the terminology of 'Indigenous water (in)justice' and 'water colonialism' [2].

Water colonialism manifests in many ways. These include, but are not limited to, dispossession, denial or erasure of Indigenous peoples' management and water diversion [21], pollution of water as a result of the state's activities, destruction of water places, and inadequate drinking water and sanitation service delivery. The literature contains detailed discussions of water colonialism's processes and impacts. For example, Phare's discussion of First Nations water rights in Canada [22] and many more, such as $[2,3,20]$.

Indigenous peoples continue to assert their sovereignty and rights to water, and to uphold their responsibilities to water. Working with creativity and strength, Indigenous peoples are using diverse strategies such as advocacy [22], nation building [23], policy development [24], teaching and sharing, practicing love for water [25], forming new governance frameworks [26], community-based water monitoring [27], developing new policy concepts such as 'cultural flows' [28] and more.

Despite Indigenous peoples' advocacy at national and international levels, states have avoided formalising Indigenous peoples' rights to water. The lack of formal rights have perpetuated what Gupta et al. describe as the 'legal and legitimate expropriation of the lands, waters, ecosystems and minerals' [29].

\subsection{UNDRIP}

This section reviews UNDRIP with attention to the water governance implications. Echoing Robison et al., this paper used UNDRIP as the 'normative backbone' of our conceptualization of Indigenous water rights and justice [2].

UNDRIP is a human rights standard. It is the most comprehensive [29] and most significant recent recognition of Indigenous peoples' rights by international law [30]. UNDRIP is often cited in discussions of Indigenous water justice and water rights. Examples include Jackson, Marshall, Taylor et al. and Askew et al. [3,20,24,31]. The Garma Declaration, the Mary River Statement, and the Assembly of First Nations National Water Declaration are examples of Indigenous peoples'/First Nations' water declarations that reference UNDRIP [22,32,33].

UNDRIP recognizes the inherent right of Indigenous peoples to self-determination. Drafted and negotiated by Indigenous people, UNDRIP was endorsed by the General Assembly in 2007, with a majority of 144 states voting in favor [34]. At the time of the vote, Australia, Canada, New Zealand and the United States voted against the UNDRIP, later reversing their position to support the UNDRIP. All countries that endorse the OECD 12 Principles on Water Governance also support UNDRIP, except for Colombia, which was one of the 11 states that abstained from the UNDRIP vote. Countries' endorsement of UNDRIP and the OECD Principles are listed in Appendix A. 
As a Declaration, rather than a Convention, UNDRIP is not legally binding under international law. Regardless, states which voted to support UNDRIP have indicated a commitment to uphold the rights within it. In some jurisdictions, the courts have started to refer to UNDRIP obligations [35]. In Canada, Bill C-262, 'An Act to ensure the laws of Canada are in harmony with the United Nations Declaration on the Rights of Indigenous Peoples,' recently passed by the House of Commons [36]. The bill requires Senate approval before coming into force. Similarly, the government of British Columbia recently committed to being 'the first province in Canada to introduce legislation to implement UNDRIP' [37]. Given the constitutional division of powers in Canada in relation to water governance, legitimizing UNDRIP in federal and provincial legislation is essential.

UNDRIP is considered to have played a 'very significant role in reshaping domestic legislation' [35]. Nevertheless, implementation is not without its challenges. The ten year review of UNDRIP indicated that, although progress has been made, implementation is not yet complete [38]. In practice, the implementation of UNDRIP has been selective, with states strategically endorsing only those norms which align with their interests [39], and exploiting any legal ambiguity by 'rule shopping' [29].

UNDRIP declares that Indigenous peoples have the right to self-determination [1]. As affirmed by Article 3 of UNDRIP, Indigenous peoples have the right to 'freely determine their political status and freely pursue their economic, social and cultural development'. Article 5 declares that Indigenous peoples have the right to maintain their distinct institutions, such as political and legal institutions. Article 25 of UNDRIP states that Indigenous peoples have the right to maintain their spiritual relationship with their lands and waters. Further, Articles 26 states that Indigenous peoples have the right to 'own, use, develop and control' their lands and resources, such as water. Indigenous peoples have the right to determine how their land and resources will be developed. According to Article 32 , states must consult with Indigenous peoples and obtain their free, prior and informed consent, operating in good faith, prior to approving any project that would affect Indigenous peoples' water, land or other resources [1].

Noting that UNDRIP's references to 'lands, territories and resources' are interpreted to include water [31], Indigenous peoples' rights to water are substantial. Indigenous peoples have the right to their own water laws, systems of water governance, and institutions, consistent with their own frameworks for water management. They have the right to maintain their spiritual relationships to water. Indigenous peoples have the right to decide if and how water resources will be developed or used. In many cases, the practical details of implementing UNDRIP are yet to be determined. Even the nature of 'free prior and informed consent,' and whether it implies a right to veto, is debated [31].

Indigenous peoples' right to govern water according to their own laws and institutions has profound implications for state water governance. UNDRIP calls for, in effect, the decolonization of water. Decolonization (i.e., the undoing of colonization) leads to material, meaningful outcomes: Repatriation of land and water. State power is potentially reduced and decentralized. Decentralization of power is one of the main threats to state water bureaucracies [40]. Perhaps by no coincidence, the debates about UNDRIP were of 'unprecedented length' compared to other UN human rights standard-setting processes, revealing the 'deeply entrenched normative and political tensions arising from the recognition of Indigenous peoples' rights' [35]. As Tuck \& Yang note, decolonization is 'unsettling' and uneasy [41]. Ultimately, UNDRIP challenges states' claims of water decisionmaking authority.

\subsection{Disambiguation: UNDRIP and the Human Right to Water}

Indigenous water justice is a human rights issue. However, it is distinct from the 'human right to water' (HRW) and to sanitation [42]. In the dominant discourse, HRW refers to basic domestic water needs i.e., water for drinking, personal sanitation, clothes washing, food preparation, and household hygiene. The UN defines the HRW as 'access to sufficient, safe, acceptable, physically accessible and affordable water for personal and domestic use'. The right to sanitation is defined as the right to 'physical and affordable access to sanitation, in all spheres of life, that is safe, hygienic, secure, and 
socially and culturally acceptable and that provides privacy and ensures dignity'. The UN has suggested a nominal volume of water to satisfy the HRW of $50 \mathrm{~L}-100 \mathrm{~L}$ per person, per day [43]. The dominant interpretation of HRW has de-politicised the concept's grassroots environmental justice origins, veiling power asymmetries and making the HRW appear to lack political content [44]. This depoliticization reproduces contested narratives about human rights and development [45]. Nevertheless, HRW continues to have value [46] and has been used to achieve a range of water access and equity goals [47].

The concept of the HRW differs from UNDRIP, as a water rights framework, in several ways. The HRW recognizes that all persons need water for life, health and dignity. Every individual has the right to water and the right to sanitation. By contrast, Indigenous water rights are collective rights that affirm Indigenous peoples are equal to all other peoples. To put it another way, the HRW can be imagined as the 'minimum' right to water and sanitation, which is distinct from subsistence rights, and also from the 'maximum,' or multi-level, rights of Indigenous peoples [29]. Another difference is that the HRW does not define the institutional structures that provide water access [6,48], whereas Indigenous water rights based on UNDRIP support self-determination via Indigenous peoples' institutions and laws. Finally, the HRW is 'abstract' in the sense that it is universal and not connected to accessing a specific water resource [49], which differs from Indigenous water rights that are located within place and history.

In sum, UNDRIP and the HRW can be viewed as two human rights standards that sit side-by-side, corresponding to connected, but different aspects of water.

\subsection{Indigenous Peoples' Water Governance Principles: Examples}

Indigenous people's water governance systems are central to achieving Indigenous water justice. It is relevant to consider the differences, if any, between the OECD Principles and Indigenous peoples' water governance approaches.

A definitive comparison is not possible because Indigenous peoples' water governance systems are heterogeneous. Furthermore, asserting a strict dichotomy between, say, 'Western' and 'Indigenous' approaches obscures diversity [31]. However, it is possible to consider specific Indigenous water governance frameworks and compare these to the OECD Principles. Here are some Canadian First Nations examples and a brief overview of some prominent Indigenous international water declarations.

The fundamental belief that water is a sacred gift is shared among Indigenous peoples in Canada. More recently, it has been codified in Indigenous political declarations that assert inherent jurisdictional authority over water, as responsibilities and obligations given by the Creator. The Assembly of First Nations National Water Declaration is a resolution of over 600 First Nations Chiefs from across Canada, that establishes an overarching framework or statement of collective water principles, grounded in an Indigenous worldview [32]. It calls for active engagement in water governance within traditional territories and treaty lands, including Indigenous customs, traditions and practices. This declaration calls upon settler state governments to 'recognize, support and affirm all First Nation Water declarations', and in doing so, reinforces other instruments, such as the provincial level Ontario Water Declaration of the Anishinaabek, Mushkegowuk and Onkwehonwe [50]. The declarations are political instruments that reaffirm constitutionally-protected inherent rights within settler states. They support First Nations actions to apply, at the local level, their own laws and governance systems, which are intricately connected to land, water and place.

For the Anishinaabek, much of whose traditional territories lie in present day Ontario, Canada, the Seven Grandfathers teachings are among the most scared laws. Considered to be spiritual gifts sent by the Creator, the Grandfathers are the original instructions for how to maintain balance and harmony with all of creation, and a way to fulfill sacred responsibilities to the Creator. Maintaining scared relationships is important to ensure the sustainability of creation's gifts. Applied to water, the seven principles of respect, wisdom, love, bravery, honesty, humility and truth, provide a path to water security [51]. They impart a moral code or decision-making framework for managing appropriate human relationships with natural systems. 
The Great Lakes Anishinaabe Seven Grandfathers and Water Governance Principles are [51]:

- Truth-to recognize the work of the creator in all things

Value water in all its forms and all its uses

- Humility - to know that each of us is part of creation and that all people are equal

Equity of all people, equity of nature, nature's rights to water

- Respect-to take care of all things the Creator has given on Mother Earth

Respect water and all of nature, and one another's views and ways

- Wisdom—to seek and share knowledge

Use water wisely and consider all forms of knowledge

- Honesty-to speak right of things-not to lie, cheat or deceive

Accountability and transparency of actions, decision-making and motives

- Love - to care and help one another

Commitment to collaboration and shared benefits

- Bravery-to be ready to face all things that are hard to do

Address immediate problems and address new conflicts from resistance to change. Shortest/quickest route is not always the best path for sustainability [51].

Similarly, the Haudenosaunee or Six Nations Confederacy of the great lakes region, are governed by Haudenosaunee law, which provides principles for responsible governance-governance founded on the understanding that all creation is interconnected and each entity has a sacred responsibility to fulfil, including water. By fulfilling responsibility, the sacred balance is achieved, and the gifts of creation will continue to provide for all.

The Haudenosaunee Constitution, known as the Great Law of Peace, is considered the 'law of the land', and at its core are three basic principles: peace, power (unity) and righteousness [52], and like the Anishinaabek, this refers to all relations, including land and water. As well, the Haudenosaunee Creation Story offers fundamental teachings on the interconnectedness between all living and non-living entities, and arguably are early origins for what we now call integrative management and ecosystem-based approaches.

Paramount is the Thanksgiving Address, or the 'words of thanksgiving,' that begin and end Haudenosaunee political and social events. Through this oral ceremony important values are shared and transmitted. Systematically giving thanks establishes a collective mind and spirit, and reinforces principles of respect, responsibility, and reciprocity. Equally relevant to water, is the Dish with One Spoon principle. Codified in Indigenous wampum, the teaching is a reminder of the collective responsibility of the people to share equally' [52]. Wampum beads are sea shells strung together to create intricate patterns with sacred and symbolic meaning. Wampum are used for official purposes and ceremonies, and narrate history, traditions or law. Early Haudenosaunee-Settler relations were often codified in wampum which were exchanged as formal agreements considered historic treaty within Indigenous law [53]. The wampum provides foundational principles for what is considered collaborative governance in current discourse. In sum, these represent only a selection of the many teachings, considered law, that illustrate how the Haudenosaunee govern their interactions with water.

Managing relationships with water through Indigenous laws, practices and beliefs, emphasizes a highly ecological or environmental approach to Indigenous water governance. But it is also important to acknowledge that Indigenous peoples face current water needs and challenges common to other populations of society. Colonialism, Western water institutions, and contemporary lifestyles have created competing social, political and economic demands for water, that in some cases have altered the spiritual relationship with water. In Canada, where Western water governance dominates, many Indigenous communities struggle for sufficient quantities of quality water to meet their basic livelihood needs [54]. Some lack potable drinking water, and water treatment facilities and infrastructure are inadequate, and human and financial capital are limited [55]. In addition to ensuring domestic needs are met, Indigenous peoples also assert rights to water and a role in governance for purposes of 
navigation and travel, irrigation, environmental protection, commercial and industrial activities, and hydro-electricity [56]. Traditional water laws, values and spirituality, within a contemporary context, highlight the importance of water governance to enable Indigenous inherent responsibilities for water, while empowering Indigenous peoples to address a diversity of water uses for current and future needs.

Some of the concepts described above are also reflected by Indigenous people's international water declarations, the Garma and Kyoto Declarations. Both declarations articulate Indigenous frameworks for water and strongly advocate for Indigenous rights. The Garma Declaration was developed Indigenous water experts in 2008 , following discussions about how to protect Indigenous interests in water and traditional knowledge. The Garma Declaration asserts that water is a spirit: 'Indigenous peoples internationally share cultural and customary responsibilities to fresh water... Water is not a commodity. Water is a spirit that has a right to be treated as an ecological entity, with its own inherent right to exist' [22]. The Kyoto Declaration from the 2003 World Water Forum is an action plan for water, declaring Indigenous peoples as caretakers, with rights and responsibilities to defend and protect water. The preface describes Indigenous peoples' relationship to water and their right to self-determination. It states that Indigenous peoples 'recognize, honor and respect water as sacred and sustaining of all life' [57].

This section provides a few reference points related to Indigenous peoples' water governance. The Haudenosaunee and Anishinaabe examples illustrate specific traditions that inform current practice, such as the water security framework based on the Anishinaabe Seven Grandfathers. The Ontario Water Declaration and National Water Declaration apply foundational principles to contemporary water challenges. The international declarations, Garma and Kyoto, assert some global commonalities in both Indigenous understandings of water and in the struggle against water colonialism.

\subsection{Strategies for Indigenous Water Justice}

Numerous solutions, strategies and mechanisms for promoting Indigenous water justice have been proposed. As mentioned previously, Indigenous peoples use a wide variety of strategies and practices to assert their rights. Much of the academic literature focuses on changes that states could or should make. These range from small changes, such as increasing Indigenous participation in state water management consultations, to complete overhauls of the ontological foundations of water governance. Examples of mechanisms include: Legislation, constitutional protection for collective rights, negotiated settlements or agreements, supporting Indigenous institutions/bodies that govern water, market mechanisms, and conferring legal personhood on rivers [30].

Some of the options are complimentary, some are mutually exclusive. Drawbacks and benefits need consideration based on contextual factors [30]. The merits of legal personhood for rivers, for example, are hotly debated. After the landmark legal precedent of Whanganui [58], there have been calls for other rivers around the world to also be given legal personhood. Nevertheless, legal scholars are concerned that, in certain contexts, the mechanism might weaken, not strengthen, Indigenous rights [59].

In addition, several frameworks have been proposed for conceptualizing the multi-dimensional issue of Indigenous water justice. The analytical model of 'representation, recognition and redistribution', proposed by Fraser [60], has been applied to Indigenous water justice [3,61]. Robison et al. discuss the themes of 'Indigenous water rights' and 'political partnership' and propose three intertwined dimensions of self-determination: socioeconomic, cultural and political self-determination [2]. Zwarteveen and Boelens propose four echelons of contestation for water: Resource access, rules, authority and discourses [4]. Water justice may also be considered through the lens of environmental justice literature [46].

Despite the array of proposed solutions and frameworks, water colonialism remains a systemic issue, perpetuated at multiple levels. This paper focuses on water colonialism in one arena: An international discourse about water governance, embodied by the OECD Principles. 


\section{Four Echelons of Water Contestation: Resources (or Relationships/Responsibilities), Rules, Authority and Discourses}

Several frameworks could provide a water justice analysis of the OECD Principles. In this article, we use Zwarteveen and Boelens' framework for water contestation [4]. The framework identifies four echelons of water struggles: Resources, rules, authority and discourses. These echelons are interrelated and shape each other. For example, the dominant discourse will shape the water management rules, that will in turn effect who can access water resources.

We deviate from the work of Zwarteveen and Boelens by adding 'relationships/responsibilities' to the 'resource' echelon. The variation highlights responsibilities to water and UNDRIP rights to maintain the spiritual relationships. The variation to the 'resource' echelon avoids a narrow view of water access that is synonymous with extractive use only.

The modified framework of water contestation is:

- Resource (or relationships/responsibilities) echelon:

Distribution of the resource: Who has access to water and for what purposes? What (non-resource) relationships to water are valued?

- Rules echelon:

Whose rules, norms and laws determine water management, distribution and allocation, and the mechanisms to acquire rights?

- Authority echelon:

Who has the authority to make decisions and enforce rights?

- Discourses echelon:

Whose discourses are used to articulate water problems and solutions?

\subsection{Analysis}

Using the four echelons of water contestation as the analytical framework, several documents were examined: The OECD Principles on Water Governance [10], OECD Council Recommendation on Water [9], the OECD Water Governance Indicator Framework [8], and Implementing the OECD Principles on Water Governance: Indicator Framework and Evolving Practices [14]. The documents were firstly searched for references to Indigenous peoples and UNDRIP. The key themes across each of the four echelons were then examined. The themes are summarized in Table 2 below.

Table 2. Water contestation themes in the reviewed documents about the OECD Principles.

\begin{tabular}{cr}
\hline Echelon of Contestation & Themes \\
\hline Discourses & HRW present in documents, UNDRIP absent. Water as an inert resource. \\
Authority & $\begin{array}{c}\text { Authority for water is assumed to be the signatory state. } \\
\text { Water conflicts are presented as cross-sectoral, rather than a direct } \\
\text { contestation of the state's authority. }\end{array}$ \\
Rules & $\begin{array}{c}\text { Rules are made by the signatory state, with input from stakeholders. } \\
\text { Indigenous people' are 'underrepresented stakeholders' to be engaged in } \\
\text { state policy design, but are not conceptualized as central policy actors. }\end{array}$ \\
\hline $\begin{array}{c}\text { Water allocation is 'non-discriminatory' and 'responsive to the customary } \\
\text { practices of traditional communities' but these are not defined. }\end{array}$ \\
relationships/responsibilities \\
$\begin{array}{c}\text { Indigenous communities are presented as a 'vulnerable group' who need to } \\
\text { be considered in relation to water service access. Human relationship to } \\
\text { water is extractive. }\end{array}$ \\
\hline
\end{tabular}

\subsection{Discourses}

In the documents reviewed, discussions of Indigenous peoples' water issues are sparse. Indigenous water justice, and the relationship between Indigenous peoples' water governance and state water governance, are not discussed in the documents. None of the documents mentioned UNDRIP. A list 
of policy domains relevant to water included finance, land use, forestry, urban development, energy production, climate change mitigation and adaptation, mining, agriculture, transport, infrastructures [9]. The list had no items related to Indigenous peoples or water tenure. Another list of 'binding, and non-binding, water-related international or supranational frameworks and regulations' and 'soft law' within the Indicator document [8], includes many items, including the sustainable development goals, but not UNDRIP.

The omissions suggest that Indigenous water justice is not considered a salient water governance issue. The HRW, in contrast, is referenced in all four documents. As noted earlier, HRW has been de-politicized and its meaning has come to support the dominant discourse, whereas UNDRIP challenges this discourse.

\subsection{Authority}

Throughout the documents, a signatory state is presented as the decision-making authority and regulator of water. Conflict management is conceptualized as a regulation and enforcement issue, presumably for the signatory state to preside over. Conflict is suggested to arise from different cross-sectoral strategies (Principle 3) or 'trade-offs' between users (Principle 11), rather than from contested claims about the primary authority.

'Indigenous' appears only once in the indicator framework's text [8]. Across the four documents, the terms 'Indigenous communities' or 'indigenous people' were used, but there are no references to Indigenous peoples in plural i.e., as distinct and diverse peoples. Indigenous peoples are referred to as 'under-represented stakeholders', to be engaged in state processes [10], or as a 'vulnerable' group in water service delivery [14]. Indigenous peoples were not listed in an example of stakeholders that could comprise a 'minimum level of representation' [8]. The sample stakeholder diagram, on page 12 of the Indicator framework, depicts 6 categories of stakeholders [8]. This example daigram places water users at the centre, followed by policy actors. 'Indigenous communities' are listed on the outer edge of the diagram within the 'underrepresented actors' category of stakeholders.

Many Indigenous people do not see themselves as 'mere' stakeholders in the water management processes run by states [62]. As clause 9 of the Kyoto Declaration explains, Indigenous peoples 'have the right to self-determination, we have the right to freely exercise full authority and control of our natural resources including water. We also refer to our right of permanent sovereignty over our resources, including water' [57].

The homogenization of Indigenous peoples can be seen within the 51 case studies 'evolving practices on water governance' on the OECD website [63]. The only Indigenous case study was submitted by an Aboriginal organization from Australia, Madjulla Inc. The case study, Practice \#41, described the Fitzroy River Declaration, a negotiated agreement between the Indigenous peoples of the Fitzroy River catchment (i.e., watershed) in Western Australia to create a governance framework, based on Indigenous laws [63]. The case study indicates that the Fitzroy Declaration was formed by a coalition of Indigenous peoples within the catchment. A summary within the OECD implementation report, however, says the Declaration was developed by 'an indigenous community'(singular) [14]. The OECD implementation report later refers to 'joint management between the government and aboriginal communities'. The Fitzroy River Declaration itself refers to joint management between the Traditional Owner groups i.e., between the Indigenous peoples [64]. The OECD implementation report's commentary focuses on stakeholder engagement. In contrast, an environmental law commentary on the Fitzroy Declaration recognized it as a negotiated agreement combining Indigenous laws and 'rights of nature,' and an Australian first [26]. The varied interpretations of this case study illustrate that agency and authority can be diminished by frameworks that see Indigenous peoples as one stakeholder among many, rather than as distinct peoples with sovereign rights and their own legal systems. 


\subsection{Rules}

As demonstrated in the previous sections, the OECD Principles are based on the assumption that signatory states have the authority for water policy and regulation. Under this assumption, stakeholders have input into the rules, but the signatory state government makes the decisions.

The OECD Principles do not prescribe specific rules. The overarching governance framework is based on three dimensions: Efficiency, effectiveness and stakeholder engagement. In contrast, the Anishinaabe Seven Grandfathers framework is based around respect, wisdom, love, bravery, honesty, humility and truth. This is just one example, but it illustrates the difference between the OECD Principles and an Indigenous approach. Conversely, parallels might be drawn between integrated water resources management (OECD Principle 2) and, for example, Haudenosaunee approaches based on interconnections of all living things.

This suggests that the OECD Principles present two problematic issues: Who makes the rules and, to a certain extent, what overarching principles are used to determine those rules.

\subsection{Resources and Relationships to Water}

The OECD Principles frame water as a resource to be managed by the water sector. Water is presented as inert, not alive nor imbued with spiritual significance. Under this framing, the relationship of humans to water is extractive. The OECD Principles dimension of trust and engagement pertains to relationships between people, excluding the relationship between humans and water. By contrast, the Anishinabek Seven Grandfather's principles provide a water security framework that values water in all forms and uses [51]. The moral code, based on respect, wisdom, love, bravery, honesty, humility and truth is applied to the relationship between humans and water.

Access to water is addressed by OECD Principle 11, 'encourage water governance frameworks that help manage trade-offs across water users, rural and urban areas, and generations'. In some of the documents, 'customary water rights' [14] and 'customary practices' [9] are referred to, but are not defined, or elaborated in relation to water entitlement distribution outcomes. The indicators refer to equity, and managing trade-offs in a way that is non-discriminatory, transparent and evidence based. However, the interpretation of equity alters radically when Indigenous peoples are framed as having sovereign rights, rather than being 'underrepresented' stakeholders.

Although this paper has not foregrounded water service provision, access to clean drinking water is a vital concern. The OECD indicator document does make specific, albeit brief, mention of water service delivery to Indigenous communities.

\section{Discussion}

The OECD Principles say that they are rooted in broader 'good governance' principles: Legitimacy, transparency, accountability, human rights, rule of law and inclusiveness [10]. Participation, dialogue and human rights are emphasized. Human rights are represented by the HRW, but an essential human rights standard is missing: UNDRIP. By not explicitly referring to Indigenous water rights, they are rendered invisible. Similarly, the Sustainable Development Goals have been criticised for not explicitly and meaningfully including Indigenous peoples in the main text [65].

The analysis suggests that the OECD Principles reflect the dominant discourse about water that privileges settler states' claims and legitimizes water colonialism. Currently, the OECD Principles place Indigenous peoples on the outer edge of water governance, as underrepresented stakeholders not policy actors. This view is problematic. Progressing Indigenous water justice outcomes requires that the relationship between states and Indigenous peoples to be reconceptualized. This relationship needs to go beyond 'stakeholder engagement' or the HRW focus of water service provision to consider Indigenous peoples' right to self-determination and water sovereignty. The Ngarrindjeri people, for example, use nation building approaches based on agreement making with the Australian 
government [23]. The shifts from 'underrepresented stakeholders' to nations, and from 'engagement' to leader-to-leader negotiations, immediately reframes Indigenous peoples' roles in water governance.

The OECD Principles' focus on inclusivity is not backed up with a basis for justice. In particular, there is an underlying assumption that each stakeholders' decision-making rights are more or less equivalent. This ignores history and disrespects Indigenous peoples' unique rights. Namely, Indigenous peoples have rights and interests described in UNDRIP, which 'derive from their political, economic and social structures and from their cultures, spiritual traditions, histories and philosophies, especially their rights to their lands, territories and resources' [34].

The exclusion of Indigenous water justice and UNDRIP cannot be dismissed as simply oversights. It is a manifestation of ideological positions about water and political interests. Implementing UNDRIP necessarily changes the discourse about authority for water, sovereignty, and the relationships between Indigenous peoples, water and states.

Like any tool, the utilization of the OECD Principles depends on who wields it and for what purpose. As a global framework for good water governance, the OECD Principles can be used for leverage and to establish legitimacy. In the Fitzroy River Declaration example, a coalition of Indigenous peoples agreed to unite to form a governance body, using a framework consistent with the OECD Principles. The Aboriginal organisation, which submitted the case study, provided an interpretation of the OECD Principles as compatible with Indigenous water governance and law. This reflects the intent of the OECD Principles to be a flexible framework. It is significant that the interpretation of the OECD Principles, to suit an Indigenous context, was then reframed by the subsequent OECD report in a way that subtly reduced Indigenous agency. This highlights the tensions between Indigenous peoples' claims and state claims about who has control over water decision making. Reinterpretations of the OECD Principles are possible but, in this case, the Indigenous narrative was somewhat effaced.

The OECD Principles' underlying assumptions about water as an inert resource further enforce state power. The OECD Principles focus on the relationships between people (water users, stakeholders, government etc.) to the exclusion of relationships between people and water. This framing is consistent with technocratic discourses that present the human relationship to water as one of production and consumption [6]. Central to dominant discourses is the 'hydraulic mission' to control and use 'every drop' of water, expanding state power [66]. The examples of Indigenous water governance principles presented earlier frame water differently: As a spirit, ancestor or family member, requiring reciprocity and respect. The Seven Grandfather's framework contains the principle to 'Respect water and all of nature'. Power and control are central to competing discourses about the relationships between humans and water.

\subsection{Reinterpreting or Reforming the OECD Prinicples}

We propose reconciling the OECD Principles with UNDRIP. The imperative to harmonise water governance and human rights approaches is particularly strong for the OECD countries with an ongoing history of water colonialism, such as Canada or Australia. Integrating Indigenous water justice into the OECD Principles requires more than inserting 'UNDRIP' into the text. Signposting the relevance of UNDRIP would be a start, but it would not address the problematic assumptions embedded in the OECD Principles. We suggest a reinterpretation or a reform.

Reinterpreting or reforming the OECD Principles based on UNDRIP could benefit states as well as Indigenous peoples. Some pragmatic arguments for implementing UNDRIP include: the cost of reputational risks if human rights obligations are not met, the relatively lower costs of resolving conflict through peaceful negotiation compared to force, and the benefits to society of Indigenous peoples' knowledge and culture, such as environmental conservation practices [38].

Reinterpreting the OECD Principles might mean developing supplementary materials for a water governance audience about UNDRIP implementation. Promoting awareness of UNDRIP is consistent with UNDRIPs 2017 review that recommended capacity building and a communications strategy [38]. Both international guidance and interpretations of UNDRIP for specific jurisdictions could be helpful. 
For example, 'Between law and action: Assessing the State of Knowledge on Indigenous Law, UNDRIP and Free, Prior and Informed Consent with reference to Fresh Water Resources' discusses UNDRIP and Canadian water law [31]. The advantage of a reinterpretation is that it could sit alongside the existing OECD Principles. Given the significant amount of work that went into developing the current OECD Principles, reinterpretation might be the easier option.

Reform is potentially more powerful than reinterpretation because it provides an opportunity to revisit the underlying assumptions and then make a coherent set of changes across the OECD Principles. Reform could result in greater consistency than reinterpreting the existing Principles.

\subsection{A New 'Water Justice' Dimension for the OECD Principles?}

What would reformed OECD Principles look like? An initial proposal is to add a 'water justice' dimension to the existing OECD Principles' dimensions of efficiency, effectiveness and trust/engagement. The 'water justice' dimension could have a corresponding set of water governance principles and indicators. The new principles might explicitly refer to UNDRIP implementation.

'Water justice' is a broad term. The proposed new dimension could encompass environmental justice issues, as well as Indigenous water justice more specifically. There is also the opportunity to consider water governance frameworks, based on reciprocity in relationships between people and water: Justice for water itself.

If the OECD Principles are reinterpreted or reformed with a clear Indigenous water justice objective, it would need to be directed by Indigenous people, and be based on input from Indigenous peoples. A first step could be to initiate a dialogue about the potential of reforming the OECD Principles to advance Indigenous water justice. A group of Indigenous water governance specialists could be invited to lead a review of the OECD Principles and discuss the option of reform.

\section{Conclusions}

In their current form, the OECD Principles delegitimize Indigenous water justice. International water governance frameworks for good governance need to be consistent not just with vague, unchallenging notions of 'human rights' but also with the specific rights and norms of UNDRIP.

Contestation for water plays out in multiple ways. Access to water resources and water entitlements is only one aspect, albeit a significant one. In this paper, we referred to four echelons of contestation: resources, rules, authority and discourses, noting that enacting relationships to water is a primary consideration beyond material access within the 'resources' echelon. The analysis across these echelons suggests that the OECD principles miss opportunities to advance Indigenous water justice. Furthermore, documentation about the OECD principles is based on dominant discourses that privilege states' control of water and understandings of water. These discourses render 'invisible' Indigenous peoples as self-determining peoples, and alternative understandings of water, such as those with a foundation of reciprocity and respect for water.

Water governance principles need to critically engage with issues of power and to ask, whose rules define water decision making? This could involve reconciling international water frameworks like the OECD principles with the human rights standards of UNDRIP. It could be possible to reinterpret, reform or even to reimagine the OECD Principles and embed an Indigenous water justice framework. Aligning international discourses about water with human rights standards might help shift discussions at the nation-state level.

We have focused on the OECD Principles as one global arena where the politics of water play out. As noted by the UN's Permanent Forum on Indigenous Issues, implementation of UNDRIP happens at all levels. The work of Indigenous peoples themselves is crucial and there are no one-size-fits-all solutions [38].

With those caveats, we put forward a proposal to reinterpret or reform the OECD Principles, providing for consideration the idea of adding a 'water justice' dimension to the OECD principles. 
Water access equity is central to water justice, but so too are issues of identity and relationships. Boelens et al. suggest that the 'struggle for control over water is a struggle for existence, and a struggle to define what existence means' [67]. McGregor describes the Anishinaabek concept of zaagidowin (or "love") as central to achieving water justice within the Anishinaabek framework. Zaagidowin can be understood as the legal principle for achieving well-being, or Mnaamodzawin. In order to achieve water justice, Mnaamodzawin needs to be realized, 'not only for people, but for the waters as well' [25].

Working towards water justice provides scope to reimagine and rebuild relationships. This includes our relationships to water, and between coloniser states and Indigenous peoples. Coming together for water could also help rebuild the relationships between Indigenous peoples that have been strained and fractured by colonisation [68]. Our initial examination of the OECD principles and Indigenous water justice is a first step only. We invite others to continue this water justice journey.

Author Contributions: Conceptualization, K.S.T. and S.L.; writing-original draft preparation, K.S.T. and S.L.; writing-review and editing, K.S.T., S.L., and R.Q.G.

Funding: This research is supported by an Australian Government Research Training Program (RTP) Scholarship.

Acknowledgments: We acknowledge all our teachers, including water.

Conflicts of Interest: The authors declare no conflict of interest. The funders had no role in the design of the study; in the collection, analyses, or interpretation of data, in the writing of the manuscript, and in the decision to publish the results. 


\section{Appendix A}

Table A1. UNDRIP signatories and countries endorsing the OECD principles.

\begin{tabular}{|c|c|c|c|}
\hline Supports UNDRIP & $\begin{array}{c}\text { Endorses the OECD } \\
\text { Principles }\end{array}$ & Country/State & Total \\
\hline $\begin{array}{c}\text { YES } \\
\text { Voted to support } \\
\text { UNDRIP }\end{array}$ & $\begin{array}{c}\text { NO } \\
\text { Has not endorsed the } \\
\text { OECD Principles }\end{array}$ & $\begin{array}{l}\text { Afghanistan; Albania; Algeria; Andorra; Angola; Antigua and Barbuda; Argentina; Armenia; Bahamas; Bahrain; } \\
\text { Barbados; Belarus; Belize; Benin; Bolivia; Bosnia and Herzegovina; Botswana; Brunei Darussalam; Bulgaria; Burkina } \\
\text { Faso; Cambodia; Cameroon; Cape Verde; Central African Republic; Chad; Comoros; Congo; Costa Rica; Cote Ivoire; } \\
\text { Croatia; Cuba; Cyprus; Democratic People's Republic Of Korea; Democratic Republic Of The Congo; Djibouti; } \\
\text { Dominica; Dominican Republic; Ecuador; Egypt; El Salvador; Equatorial Guinea; Eritrea; Ethiopia; Fiji; Gabon; Gambia; } \\
\text { Ghana; Grenada; Guatemala; Guinea; Guinea-Bissau; Guyana; Haiti; Honduras; India; Indonesia; Iran; Islamic } \\
\text { Republic Of Iraq; Jamaica; Jordan; The Republic Of Kazakhstan; Republic Of Kiribati; Kuwait; Kyrgyzstan; Lao } \\
\text { People's Democratic Republic; Lebanon; Lesotho; Liberia; Libyan Arab Jamahiriya; Liechtenstein; Lithuania; } \\
\text { Madagascar; Malawi; Malaysia; Maldives; Mali; Malta; Marshall Islands; Mauritania; Mauritius; Micronesia; Federated } \\
\text { States Of Moldova; Monaco; Mongolia; Montenegro; Mozambique; Myanmar; Namibia; Republic Of Nauru; Nepal; } \\
\text { Nicaragua; Niger; Oman; Pakistan; Palau; Panama; Papua New Guinea; Paraguay; Philippines; Qatar; Rwanda; Saint } \\
\text { Kitts And Nevis; Saint Lucia; Saint Vincent And The Grenadines; San Marino; Sao Tome And Principe; Saudi Arabia; } \\
\text { Senegal; Serbia; Seychelles; Sierra Leone; Singapore; Solomon; Islands Somalia; Sri Lanka; Sudan; Suriname; Swaziland; } \\
\text { Syrian Arab Republic; Tajikistan; Thailand; The Former Yugoslav; Republic Of Macedonia Timor-Leste; Togo; Kingdom } \\
\text { Of Tonga; Trinidad And Tobago; Tunisia; Turkmenistan; Tuvalu; Uganda; United Arab Emirates; United Republic Of } \\
\text { Tanzania; Uruguay; Uzbekistan; Vanuatu; Bolivarian Republic Of .Venezuela; Vietnam; Yemen; Zambia; Zimbabwe }\end{array}$ & 92 \\
\hline $\begin{array}{c}\text { YES } \\
\text { Voted to support } \\
\text { UNDRIP }\end{array}$ & $\begin{array}{c}\text { YES } \\
\text { Endorsed the OECD } \\
\text { Principles }\end{array}$ & $\begin{array}{l}\text { [OECD countries] Australia*; Austria; Belgium; Canada*; Chile; Czech Republic; Denmark; Estonia; Finland; France; } \\
\text { Germany; Greece; Hungary; Iceland; Ireland; Israel; Italy; Japan; Latvia; Luxemburg; Republic of Korea; Mexico; } \\
\text { Netherlands; New Zealand*; Norway; Poland; Portugal; Slovakia; Slovenia; Spain; Sweden; Switzerland; Turkey; } \\
\text { United Kingdom; United States* } \\
\text { [Non-OECD countries] Brazil; China; Morocco; Peru; Romania; South Africa } \\
\text { *[Australia, Canada, New Zealand and the United States initially voted against UNDRIP but later reversed the decision] }\end{array}$ & 41 \\
\hline $\begin{array}{c}\mathrm{NO} \\
\text { Abstained from vote }\end{array}$ & $\begin{array}{c}\text { YES } \\
\text { Endorsed the OECD } \\
\text { Principles }\end{array}$ & Colombia & 1 \\
\hline $\begin{array}{c}\mathrm{NO} \\
\text { Abstained from vote }\end{array}$ & $\begin{array}{c}\text { NO } \\
\text { Has not endorsed the } \\
\text { OECD Principles }\end{array}$ & Azerbaijan; Bangladesh; Bhutan; Burundi; Georgia; Kenya; Nigeria; Russian Federation; Samoa; Ukraine & 10 \\
\hline
\end{tabular}

Data sources: UNDRIP endorsement [34]; OECD endorsement [11]. 


\section{References}

1. United Nations Declaration on the Rights of Indigenous Peoples. 2007. Available online: https://waubrafoundati on.org.au/wp-content/uploads/2014/06/United-Nations-Declaration-on-the-Rights-of-Indigenous-Peoples.pdf (accessed on 16 October 2018).

2. Robison, J.; Cosens, B.A.; Jackson, S.; Leonard, K.; McCool, D. Indigenous Water Justice. SSRN Electron. J. 2017. [CrossRef]

3. Jackson, S. Indigenous Peoples and Water Justice in a Globalizing World. In The Oxford Handbook of Water Politics and Policy; Conca, K., Weinthal, E., Eds.; Oxford University Press: Oxford, UK, 2016.

4. Zwarteveen, M.Z.; Boelens, R. Defining, researching and struggling for water justice: Some conceptual building blocks for research and action. Water Int. 2014, 39, 143-158. [CrossRef]

5. Moggridge, B.; Mihinui, R. National Water Quality Management Strategy (NWQMS) 2018_Indigenous Principles for Water Quality. Australian and New Zealand Guidelines for Fresh and Marine Water Quality; Water Quality Australia: Canberra, Australia, 2018.

6. Perreault, T. What kind of governance for what kind of equity? Towards a theorization of justice in water governance. Water Int. 2014, 39, 233-245. [CrossRef]

7. Organisation for Economic Co-operation and Development OECD Principles on Water Governance. 2019. Available online: http://www.oecd.org/governance/oecd-principles-on-water-governance.htm (accessed on 1 September 2017).

8. Organisation for Economic Co-operation and Development OECD Water Governance Indicator Framework 2018. Available online: http://www.oecd.org/regional/OECD-Water-Governance-Indicator-Framework.pdf (accessed on 25 November 2018).

9. Organisation for Economic Co-operation and Development OECD Council Recommendation on Water. Available online: https://www.oecd.org/environment/resources/Council-Recommendation-on-water.pdf (accessed on 25 November 2018).

10. Organisation for Economic Co-operation and Development OECD Principles on Water Governance. 2015. Available online: http://www.oecd.org/cfe/regional-policy/OECD-Principles-on-Water-Governance.pdf (accessed on 25 November 2018).

11. Organisation for Economic Co-operation and Development Global Coalitions for Good Water Governance: Launched at the 2016 World Water Week in Stockholm, Sweden. Available online: https://www.oecd.org/cfe /regional-policy/Global-Coalition-Good-Water-Governance-Flyer.pdf (accessed on 25 November 2018).

12. Organisation for Economic Co-operation and Development, About the OECD. Available online: https: //www.oecd.org/about/ (accessed on 30 March 2019).

13. Organisation for Economic Co-operation and Development History: OECD. Available online: http://www.oe cd.org/about/history/ (accessed on 7 December 2018).

14. Organisation for Economic Co-operation and Development. Implementing the OECD Principles on Water Governance: Indicator Framework and Evolving Practices; OECD Studies on Water; OECD: Paris, France, 2018; ISBN 978-92-64-29266-6.

15. Organisation for Economic Co-operation and Development OECD Water Governance Initiative: Achievements and Ways Forward. March 2016. Available online: http://www.oecd.org/cfe/regional-policy/W GI-Achievements-Ways-Forward.pdf (accessed on 25 March 2019).

16. Akhmouch, A.; Clavreul, D. Stakeholder Engagement for Inclusive Water Governance: "Practicing What We Preach" with the OECD Water Governance Initiative. Water 2016, 8, 204. [CrossRef]

17. Neto, S.; Camkin, J.; Fenemor, A.; Tan, P.-L.; Baptista, J.M.; Ribeiro, M.; Schulze, R.; Stuart-Hill, S.; Spray, C.; Elfithri, R. OECD Principles on Water Governance in practice: An assessment of existing frameworks in Europe, Asia-Pacific, Africa and South America. Water Int. 2018, 43, 60-89. [CrossRef]

18. Colon, M.; Richard, S.; Roche, P.-A. The evolution of water governance in France from the 1960s: Disputes as major drivers for radical changes within a consensual framework. Water Int. 2018, 43, 109-132. [CrossRef]

19. Seijger, C.; Brouwer, S.; van Buuren, A.; Gilissen, H.K.; van Rijswick, M.; Hendriks, M. Functions of OECD Water Governance Principles in assessing water governance practices: Assessing the Dutch Flood Protection Programme. Water Int. 2018, 43, 90-108. [CrossRef]

20. Marshall, V. Overturning Aqua Nullius; Aboriginal Studies Press: Canberra, Australia, 2017; ISBN 978-1922059-09-3. 
21. Jackson, S.; Barber, M. Historical and contemporary waterscapes of North Australia: Indigenous attitudes to dams and water diversions. Water Hist. 2016, 8, 385-404. [CrossRef]

22. Phare, M.-A.S. Denying the Source; Rocky Mountain Books Ltd: Victoria, BC, Canada, 2011; ISBN 978-1926855-17-2.

23. International Indigenous Water Experts Forum. Garma International Indigenous Water Declaration; Garma Conference: Gulkula, Northern Territory, 2008. Available online: http://www.savanna.org.au/nailsma/publi cations/garma_water_declaration.html (accessed on 15 August 2017).

24. Hemming, S.; Rigney, D.; Muller, S.; Rigney, G.; Campbell, I. A new direction for water management? Indigenous nation building as a strategy for river health. Ecol. Soc. 2017, 22, 13. [CrossRef]

25. Taylor, K.S.; Moggridge, B.J.; Poelina, A. Australian Indigenous Water Policy and the impacts of the ever-changing political cycle. Australas. J. Water Resour. 2016, 20, 132-147. [CrossRef]

26. McGregor, D. Indigenous Women, Water Justice and Zaagidowin (Love). Can. Woman Stud. Downsview 2013, 30, 71-78.

27. Lim, M.; Poelina, A.; Bagnall, D. Can the Fitzroy River Declaration ensure the realisation of the First Laws of the River and secure sustainable and equitable futures for the West Kimberley? Aust. Environ. Rev. 2017, 32, $18-24$.

28. Wilson, N.J. Indigenous water governance: Insights from the hydrosocial relations of the Koyukon Athabascan village of Ruby, Alaska. Geoforum 2014, 57,1-11. [CrossRef]

29. Nelson, R.; Godden, L.; Lindsay, B. A Pathway to Cultural Flows in Australia National Cultural Flows Project. Murray Lower Darling Rivers Indigenous Nations (MLDRIN), Northern Basin Aboriginal Nations (NBAN) \& North Australian Indigenous Land and Sea Management Alliance (NAILSMA): Australia. 2018. Available online: http://www.culturalflows.com.au/images/documents/Law\%20and\%20Policy\%20Summary. pdf (accessed on 15 March 2019).

30. Gupta, J.; Hildering, A.; Misiedjan, D. Indigenous people's right to water under international law: A legal pluralism perspective. Curr. Opin. Environ. Sustain. 2014, 11, 26-33. [CrossRef]

31. Jackson, S. Water and Indigenous rights: Mechanisms and pathways of recognition, representation, and redistribution. Wiley Interdiscip. Rev. Water 2018, 5, e1314. [CrossRef]

32. Askew, H.; Snelgrove, C.; Wrightson, K.R.; Courturier, D.; Koebel, A.; Nowlan, L.; Bakker, K. Between Law and Action: Assessing the State of Knowledge on Indigenous Law, UNDRIP and Free, Prior and Informed Consent with reference to Fresh Water Resources; West Coast Environmental Law, Social Sciences and Humanities Research Council of Canada: Ottowa, ON, Canada, 2017.

33. Assembly of First Nations National Water Declaration. Available online: https://www.afn.ca/uploads/files/w ater/national_water_declaration.pdf (accessed on 8 December 2018).

34. Delegates of the Mary River Water Forum. Mary River Statement. 2009. Available online: https://www.enviro nment.sa.gov.au/files/sharedassets/public/corporate/about_us/aboriginal_partnerships/mary-river-statement. pdf (accessed on 13 April 2019).

35. The United Nations United Nations Declaration on the Rights of Indigenous Peoples. Available online: https://www.un.org/development/desa/indigenouspeoples/declaration-on-the-rights-of-indigen ous-peoples.html (accessed on 16 October 2018).

36. Hohmann, J.; Weller, M. The UN Declaration on the Rights of Indigenous Peoples: A Commentary, 1st ed.; Hohmann, J., Weller, M., Eds.; Oxford commentaries on international law; Oxford University Press: Oxford, UK, 2018; ISBN 978-0-19-967322-3.

37. House of Commons, Canada Bill C-262. An Act to ensure that the laws of Canada are in harmony with the United Nations Declaration on the Rights of Indigenous Peoples. 2019. Available online: https://www.parl.ca/LegisInfo/BillDetails.aspx?billId=8160636\&Language=E (accessed on 1 April 2019).

38. Speech from the Throne to Open the Fourth Session. 2019. Available online: https://www.leg.bc.ca/content/ data\%20-\%20ldp/Pages/41st4th/ThroneSpeech_2019.pdf (accessed on 1 April 2019).

39. Permanent Forum on Indigenous Issues International Expert Group Meeting on the Theme "Implementation of the United Nations Declaration on the Rights of Indigenous Peoples: The Role of the Permanent Forum on Indigenous Issues and Other Indigenous-Specific Mechanisms (article 42)". Available online: http://www.un.org/en/ga/search/view_doc.asp?symbol=E/C.19/2017/10 (accessed on 30 January 2019).

40. Lightfoot, S.R. Selective endorsement without intent to implement: Indigenous rights and the Anglosphere. Int. J. Hum. Rights 2012, 16, 100-122. [CrossRef] 
41. Molle, F.; Mollinga, P.; Wester, P. Hydraulic Bureaucracies and the Hydraulic Mission: Flows of Water, Flows of Power. Water Altern. 2009, 2, 328-349.

42. Tuck, E.; Yang, K.W. Decolonization is not a metaphor. Decolonization Indig. Educ. Soc. 2012, 1, 1-40.

43. UN-Water Human Rights to Water and Sanitation. Available online: http://www.unwater.org/water-facts/hu man-rights/ (accessed on 4 February 2019).

44. United Nations. The Right to Water. Fact Sheet No. 35. Available online: https://www.ohchr.org/Documents/ Publications/FactSheet35en.pdf (accessed on 4 February 2019).

45. Parmar, P. Revisiting the Human Right to Water. Aust. Fem. Law J. Nathan 2008, 28, 77-96. [CrossRef]

46. Prieto, M. The Right to Water: Politics, Governance and Social Struggles edited by Farhana Sultana and Alex Loftus (eds). Earthscan, Oxon, 2012, pp. xvii + 262 (ISBN 978-1-84971-359-7). Singap. J. Trop. Geogr. 2015, 36, 136-137. [CrossRef]

47. Harris, L.M.; Rodina, L.; Morinville, C. Revisiting the Human Right to Water from an environmental justice lens. Polit. Groups Identities 2015, 3, 660-665. [CrossRef]

48. Mirosa, O.; Harris, L.M. Human Right to Water: Contemporary Challenges and Contours of a Global Debate. Antipode 2012, 44, 932-949. [CrossRef]

49. Bakker, K. The "Commons" Versus the "Commodity": Alter-globalization, Anti-privatization and the Human Right to Water in the Global South. Antipode 2007, 39, 430-455. [CrossRef]

50. Hodgson, S. Exploring the Concept of Water Tenure; Food and Agriculture Organisation of the United Nations: Rome, Italy, 2016.

51. Chiefs of Ontario Water Declaration of the Anishinaabek, Mushkegowuk and Onkwehonwe. Available online: http://www.abpages.ca/sites/default/files/files/COO\%20water\%20declaration\%20revised\%20march \%202010.pdf (accessed on 18 April 2018).

52. Longboat, S. First Nations Water Security: Security for Mother Earth. Can. Woman Stud. Downsview 2013, 30, 6-13.

53. King, J.T. The value of water and the meaning of water law for the Native Americans known as the Haudenosaunee. Cornell J. Law Public Policy 2006, 16, 449.

54. Haudenosaunee Confederacy Wampum. Available online: https://www.haudenosauneeconfederacy.com/w ampum/ (accessed on 10 December 2018).

55. O'Connor, D.R. Chapter 15 First Nations. In Part Two, Report of the Walkerton Inquiry: A Strategy for Safe Drinking Water; Ontario Ministry of the Attorney General: Toronto, ON, Canada, 2002.

56. Phare, M.-A.S. Restoring the Lifeblood: Water, First Nations and Opportunities for Change: Background Report; Walter and Duncan Gordon Foundation: Toronto, ON, Canada, 2012.

57. Delegates of the Third World Water Forum. Indigenous Peoples Kyoto Water Declaration; Third World Water Forum: Kyoto, Japan, 2003.

58. Charpleix, L. The Whanganui River as Te Awa Tupua: Place-based law in a legally pluralistic society. Geogr. J. 2017, 184, 19-30. [CrossRef]

59. Curran, D. Independent Legal Personhood of Rivers or Relational Stewardship? A Perspective from 20 Percent of the Worlds Freshwater (Canada) and the Indigenous-Colonial Legal Tensions that Govern it. Available online: https://www.internationalwaterlaw.org/blog/2018/05/23/independent-legal-personhood-ofrivers-or-relational-stewardship-a-perspective-from-20-percent-of-the-worlds-freshwater-canada-and-t he-indigenous-colonial-legal-tensions-that-govern-it/ (accessed on 23 May 2018).

60. Fraser, N. Reframing Justice in a Globalizing World. New Left Rev. 2005, 36, 69-88.

61. Jackson, S.; Barber, M. Recognition of indigenous water values in Australia's Northern Territory: current progress and ongoing challenges for social justice in water planning. Plan. Theory Pract. 2013, 14, 435-454. [CrossRef]

62. Tan, P.-L.; Bowmer, K.H.; Mackenzie, J. Deliberative tools for meeting the challenges of water planning in Australia. J. Hydrol. 2012, 474, 2-10. [CrossRef]

63. Evolving Practices on Water Governance|OECD READ Edition. Available online: http://www.keepeek.com/Di gital-Asset-Management/oecd/environment/implementing-the-oecd-principles-on-water-governance/evolv ing-practices-on-water-governance_9789264292659-6-en (accessed on 22 March 2018).

64. Kimberley Land Council Fitzroy River Declaration. Available online: Availablefromhttp://www.klc.org.au/n ews-media/newsroom/news-detail/2016/11/15/kimberley-traditional-owners-unite-for-the-fitzroy-river (accessed on 8 May 2017). 
65. Indigenous Peoples' Major Group Open Working Group on SDGs 13th Session. Statement of the Indigenous Peoples' Major Group. United Nations, New York. Available online: https://sustainabledevelopment.un.org/ content/documents/10918IPMG.pdf (accessed on 3 March 2019).

66. Wester, P. Capturing the waters: The hydraulic mission in the Lerma-Chapala Basin, Mexico (1876-1976). Water Hist. 2009, 1, 9-29. [CrossRef]

67. Boelens, R.; Zwarteveen, M. Prices and Politics in Andean Water Reforms. Dev. Change 2005, 36, 735-758. [CrossRef]

68. Poelina, A.; Taylor, K.S.; Perdrisat, I. Martuwarra Fitzroy River Council: a cultural approach to collaborative water governance in an Aboriginal and National Heritage listed area. Australas. J. Environ. Manag. 2019, in press.

(C) 2019 by the authors. Licensee MDPI, Basel, Switzerland. This article is an open access article distributed under the terms and conditions of the Creative Commons Attribution (CC BY) license (http://creativecommons.org/licenses/by/4.0/). 